\title{
CONFLICT AND EMPLOYMENT RELATIONS
} IN THE INDIVIDUAL RIGHTS ERA

ALEXANDER J.S. COLVIN

Cornell University 


\begin{abstract}
Purpose - The decline of collective representation and rise of individual employment rights is a transformative shift in employment relations that has changed the landscape of workplace dispute resolution. I propose a model that seeks to provide a new approach to understanding how workplace dispute resolution functions in the era of individual employment rights.
\end{abstract}

Methodology/approach - The model I propose focuses the analysis on the elements that connect the structure of rights that are enacted to the patterns of employment practices in the workplace.

Findings - My argument is that the systems for enforcement of individual employment rights and the mechanisms of representation for the employees affected are as important as the substantive rights themselves in determining the impact of the individual rights regime. These three elements combine to determine the degree to which the individual employment rights serve as an effective source of power for employees in relation to their employers.

Research implications - The establishment of these sources of power is what then results in the individual rights regime producing an effect on the employers' patterns of practices in the workplace and ultimately determining the nature and character of the employment relationship.

Keywords: Conflict resolution; dispute resolution; industrial relations; labor relations; employment law; individual rights 


\section{CONFLICT AND EMPLOYMENT RELATIONS IN THE INDIVIDUAL RIGHTS ERA}

The field of industrial relations has undergone a fundamental transformation in recent decades. Collective bargaining and union representation, which traditionally lay at the heart of this field of study, have experienced widespread disruption and decline. This trend has been particularly strong in the liberal economies of the Anglo-American world (Colvin \& Darbishire, 2013). Following the conservative revolution of the elections of Thatcher and Reagan, public policy in the United Kingdom and the United States shifted sharply away from support for collective bargaining, encouraging rising employer efforts to avoid unions that led to a contraction of union representation and weakened bargaining power for the unions that remained. The epic public policy battles over industrial relations system reform in Australia and New Zealand resulted in the disruption of the formerly centralized Award systems and a much more narrowly confined role for unions. Meanwhile the coordinated market economies of continental Europe no longer represent the unchallenged union strongholds that they once were. Notably Germany, the traditional exemplar of union centered industrial relations, has begun to shift dramatically with declining levels of collective agreement coverage, more decentralized arrangements, and a rapidly growing secondary labor market of lower paid workers on precarious contracts (Doellgast \& Greer, 2007). Looking at the great arc of history, collective bargaining, and industrial relations with it, appears to be clearly on a downward trajectory.

Yet when we take a broader perspective on employment relations, the judgment of history seems less clear. This same period of declining collective representation is also the era of the individual rights revolution in employment relations. If we go back a half century to when industrial relations was in its heyday and the lions of the field could hopefully project the worldwide expansion of collective bargaining (Kerr, Dunlop, Harbison, \& Myers, 1964), the field of individual employment rights was largely an afterthought relevant mainly to police the relatively small segment of employers competing on the lower margins of the labor market. 
From the 1960s onward, however, it was individual employment rights not collective bargaining that steadily expanded and became an increasingly widespread mechanism for structuring the employment relationship. In the United States, this individual rights revolution focused particularly on the area of employment discrimination, beginning with the landmark Civil Rights Act of 1964, extending through additional anti-discrimination legislation and blossoming into the current complex system of employment litigation (Colvin, 2012). In the United Kingdom, there were the beginnings of an individual rights-based system with the introduction of legal protections against unfair dismissal in 1971 enforced through the Employment Tribunals system. More recently it is striking that the return of the Labour Party to power in 1997 produced little if any revival in union fortunes, but did produce the UK's first minimum wage law, strengthen employment standards, and bring forth rising numbers of individual employment rights disputes (Dix, Sisson, \& Forth, 2009). In Australia and New Zealand, as well, the decline in union representation has been accompanied by an expansion of minimum employment standards (Colvin \& Darbishire, 2013). Even in Germany, there has been a large increase in the numbers of individual employment disputes in that country's labor courts, paralleling the similar growth in numbers of cases in the employment tribunals and courts of the United Kingdom and United States (Schneider, 2001). Looking again at the great arc of historical change, unlike collective bargaining, individual employment rights are clearly on an upward trajectory.

Although industrial relations researchers have begun to investigate the new areas of individual employment rights (e.g., Colvin, 2003a, 2003b; Colvin \& Gough, 2015; Currie \& Teague, 2016; Lipsky, Seeber, \& Fincher, 2003; Roche \& Teague, 2012a; Roche, Teague, \& Colvin, 2014; Wheeler, Klaas, \& Mahony, 2004), the field's more general theories and models have not caught up with the shifting nature of employment relations. The foundational work in the industrial relations field, notably that of Commons and the Webbs, was framed in a setting where unions and collective bargaining were being established as institutions to govern employment relations, leading them to address such important questions of that era as what led unions to expand (Commons, 1909) and what types of strategies organized labor used to 
advance worker interests (Webb \& Webb, 1897). In the mid-20th century period of ascendency of the industrial relations field, the leading theories focused even more intensely on collective bargaining (Kaufman, 1993). In the United States, the foremost theoretical model put forward by Dunlop (1958) presented the idea of an industrial relations system operating with unions and employers as its key actors. Similarly in the United Kingdom, much of the leading industrial relations research of the 1960 s and 1970s, whether from pluralist or radical perspectives, sought to understand and explain the features of the then dominant world of unionmanagement relations and its central processes of collective bargaining, strikes, and shop-floor labor relations (e.g., Clegg, 1970; Flanders, 1970; Fox \& Flanders, 1969; Hyman, 1972). More recently, the Transformation theory advanced by Kochan, Katz, and McKersie (1986) provided a more dynamic perspective on change in industrial relations systems, but focused on understanding the decline in collective bargaining and did not address the rise of individual employment rights. Similarly, Kelly's (1998) theory of social movements provided us insights into newer forms of collective action, but did not help us understand the nature of individual rights-based employment relations.

The danger, as Piore and Safford (2006) have observed, is that the field of industrial relations in its focus on collective representation is failing to adequately address a transformation in employment relations that has already occurred with the rise of individual employment rights. To speak to the major problems and concerns of our times, as a field industrial relations needs to develop theories and analyses that help us understand how employment relations operate in the setting where most employees are not represented by unions and where individual employment rights and not collective bargaining is the major influence on their employment.

In this chapter, I will propose an approach to theorizing employment relations in the current era and apply it to analyze individual employment rights conflicts and their impact on employment relations. My focal examples will draw on the experiences in the United States, which provides the leading edge exemplar of an individualized, rights-based system of 
employment relations, but I will also contrast this with parallel developments in other countries.

The model I am proposing includes three components that capture the institutional framework for how individual rights are enacted and realized. First, there is a structure of substantive employment rights the formal employment protections typically enacted through statutes and regulations and enunciated in court decisions. Second, there is a system of enforcement, the set of procedures and practices through which employment rights and rules are enforced and implemented. Third, there is a mechanism of representation the process by which employee interests are articulated and realized. Together these three components of the institutional framework combine to provide the source of employee power, which is the fourth component of the model. Employee power is a key intermediary construct in this model, serving as the conduit through which individual employment rights influence employment outcomes. The last component of the model is the patterns of employer practices that are the focal outcome. This model is illustrated in Fig. 1. As shown in the figure, I will also describe recursive paths in the model, where structures of rights, systems of enforcement, and mechanisms of representation are also influenced by and respond to the patterns of practices produced by the interactions in the model. 
Institutional Framework

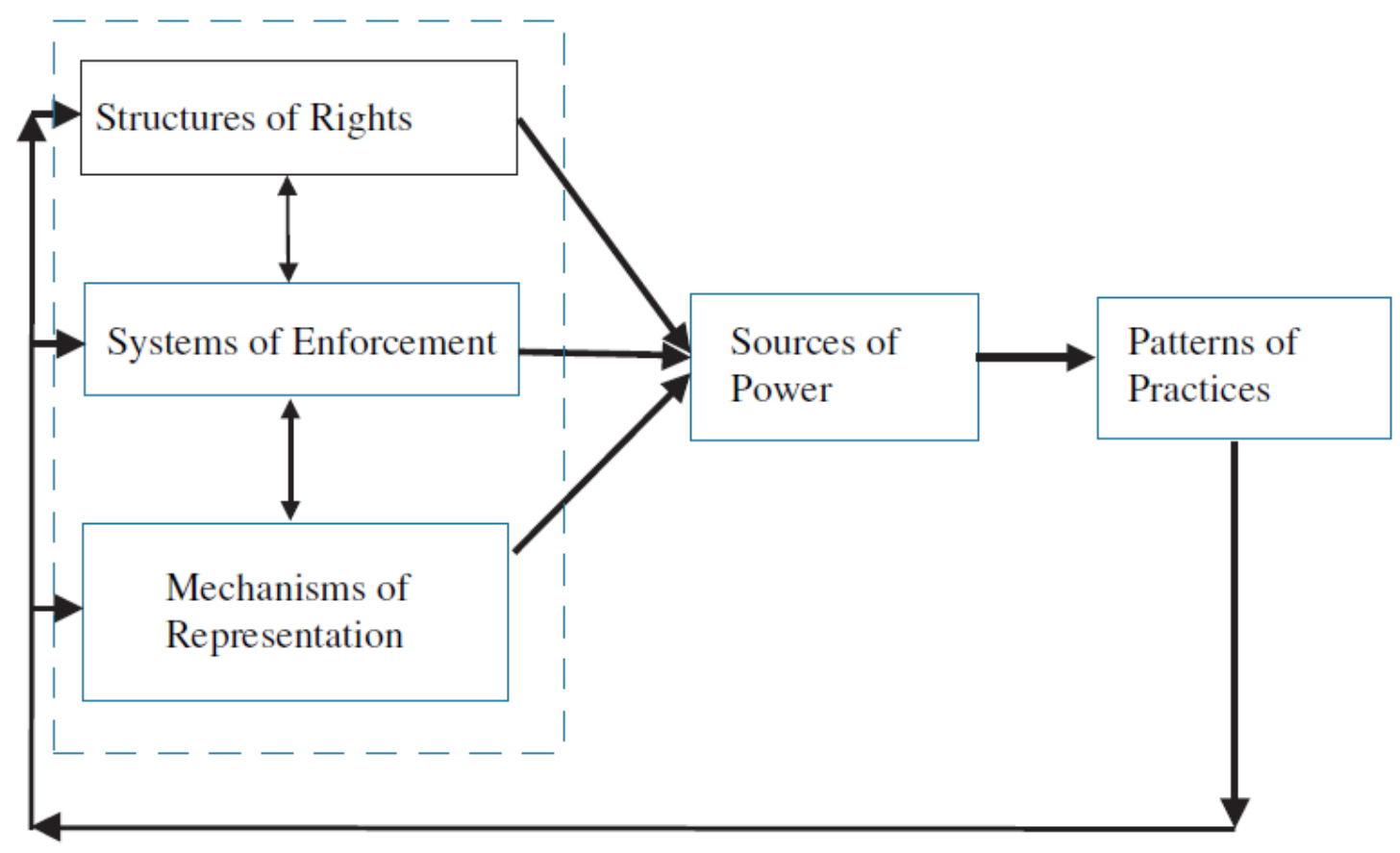

Fig. 1. Model of Individual Rights Employment Relations.

\section{CONCEPTUALIZING INDIVIDUAL RIGHTS ERA EMPLOYMENT RELATIONS}

If we are to develop an approach to understanding individual rights era employment relations, what insights can we draw from past industrial relations theory and research that can be adapted to this new setting? In my view there are three touchstones to an industrial relations-based approach that we should build upon: institutions, power, and conflict.

First, recognizing the importance of institutions, not just as a constraint on the behavior of actors and markets but rather as foundational elements structuring the nature of employment relations, has been a central contribution of industrial relations research. In the individual rights setting, this suggests the importance of going beyond the formal enunciated set of enacted laws or rights to analyze how the new institutions structure and reshape the 
employment relationship.

Second, endemic imbalances of bargaining power between employers and employees provided a focal concern for the development of the industrial relations field. In the heyday of collective bargaining and union strength in the mid-20th century, contests of bargaining power were often more evenly balanced between organized labor and management, arguably shifting the emphasis of theory and research away from issues of unequal power. In the present era of heightened employer power and diminished union strength, a central concern to be addressed is to what degree individual employment rights provide a new source of employee power in the employment relationship.

Third, the industrial relations perspective has traditionally seen conflict as inherent in the nature of the employment relationship. For understanding individual employment rights, this means that rather than view conflicts over rights as something residual that occurs in marginal cases of employer deviance, we should view conflict in the individual employment rights era as inherent in employment relations in this setting. We should see it as a central process through which the individual employment relationship is shaped.

The approach I am proposing here is one that is clearly rooted in the institutionalist research tradition. However that tradition, particularly in its American Dunlopian variant, has been criticized, in my view rightly, from more critical perspectives for failing to take sufficient account of issues of power and conflict (e.g., Godard, 2014, chapter 2; Hyman, 1975). By bringing conflict and power more centrally into the analysis of the role of institutions, the perspective that I am proposing is one of critical institutionalism.

Using these starting points, how should we approach analyzing individual rights era employment relations? I will argue there are five important components of how individual employment rights operate and that their combined operations characterize the nature of employment relations in this era. The first component is the structure of rights that employees 
have. This includes the substantive employment rights and standards enacted under employment laws. But it also includes the structure of who is entitled to the protections of these rights and what is the process for determining coverage of the laws.

The second component is the system of enforcement of employment rights. Absent an effective process to enforce employment rights, they will remain laws on the books rather than laws in practice. These systems vary by country and include the activities of government investigators, specialized labor courts and employment tribunals, and in some countries the general court system. They may also include private arbitration and other alternative dispute resolution procedures in some countries. They can include both rights-based processes, such as litigation and arbitration, and interest-based processes, such as mediation. They may also include multistage procedures and combinations of rights-based and interest-based options that operate together as a system to provide for more effective realization and enforcement of employment rights.

The third component is the mechanism of representation for employees. To effectively articulate and enforce individual employment rights it is critical that there be some well-functioning mechanism for providing representation for employees. One of the strengths of collective bargaining systems is that unions provide an effective mechanism for representation through organizing collective action and, depending on the system, financing of representation through union dues and other sources of union finances. In the context of individual employment rights, organizing and financing individual employee representation is a much greater challenge and can undermine the operation of the system.

The fourth component is the sources of power available to employees. In the traditional industrial relations realm of collective bargaining, the strike weapon, either explicitly or implicitly, served as the source of countervailing collective power for labor in dealing with employers. In the individual employment rights realm, the threat of legal and other sanctions for violation of employee rights serves a parallel function as a source of countervailing 
employee power checking the workplace authority and power of management.

The fifth component is the pattern of practices of employment within organizations. An effective individual employment rights system does not operate at a level removed from the workplace, but rather by altering employment relations practices and behavior within organizations. This can consist of individual practices, such as how an employer handles core human resource functions of selecting, training, compensating, or disciplining employees. These individual employment practices and decisions can be subject to the influence of individual employment rights. But it also includes the broader patterns of practices found outside a specific work environment but within work and employment systems in general.

The relationships among these five components are illustrated in Fig. 1. The combination of the structure of rights, the system of enforcement, and the mechanism of representation provide the basis for the sources of power for employees. These sources of power operate together to influence the pattern of practices within organizations, which is the key outcome of the system. These patterns of practices reflecting the employment system of the workplace then in turn help determine the degree to which individual employment rights are respected and incorporated into the employment relationship for individual workers.

\section{ELABORATION AND APPLICATION OF THE MODEL}

In this section I will elaborate on the model and apply it to analyze the state of individual rights era employment relations. Although I will compare the situation in different countries, I will focus on the experience of the United States as providing the paradigmatic example for employment relations focusing on individual employment rights. The United States is the country that has seen the longest and deepest deterioration of collective representation and correspondingly the greatest shift over to an individualized model of employment relations. Given its role as an exemplar of a liberalized labor market in worldwide debates on labor 
relations reform, it is particularly important to understand how its individual employment rights-based system functions as an alternative. In order to provide a more generalizable model, I will also discuss the American model in comparative perspective and attempt to identify from the differences between it and other countries how the distinctive features of the individual employment rights system in the United States drive the nature of its employment relations.

\section{Structures of Rights}

If we want to understand the individual employment rights system, we need to begin with the substantive rights it offers employees. Different national systems offer different types of substantive rights protections and varying extents of entitlements within these rights. These differences in the structure of substantive rights also extend into the scope of coverage of employees by these rights.

In the United States, it is employment discrimination laws that are the crown jewels of the individual employment rights system. Beginning with the landmark Civil Rights Act of 1964, which sought to end institutionalized segregation in America, employment discrimination laws have been a central focus of employment rights legislation (Estlund, 2010). Initially, Title VII of the Civil Rights Act began with prohibitions on discrimination in employment based on race, color, sex, religion, and national origin. This was extended to include areas such as age discrimination, pregnancy discrimination, and sexual harassment. Even following the 1980s conservative shift in American politics, the early 1990s saw the extension of employment rights to include protections against disability discrimination and the substantial strengthening of the Civil Rights Act through a comprehensive set of amendments in 1991. In subsequent years, continued extension of the individual employment rights regime has mostly been at the state level, with a number of states adding protections against discrimination in areas such as sexual orientation, non-work lifestyles, and "smokers' rights." 
Discrimination law is an area where the United States has been a leader with many other countries following its example in introducing employment discrimination statutes from the 1960s onward. None provide the same levels of sanctions for discrimination in employment as does American law, however. By contrast, in other areas of individual employment rights, the United States is more of an outlier in the limited extent of its employment protections.

In the area of employment standards laws, there has been an increasing convergence across countries in recent years, particularly in the Anglo- American world (Colvin \& Darbishire, 2013). We now see a common basket of minimum standards protections entitling employees to minimum wages, standard holidays, annual vacations, and parental leaves, among other items. The convergence in this area in recent years is noteworthy, including such changes as the adoption of minimum wage laws in the United Kingdom in the late 1990s and of paid parental leave in Australia. The package of basic employment standards is now remarkably similar across the Anglo-American countries. The one major outlier is the United States, which continues to lack basic entitlements to sick leave, annual vacation, and paid parental leave. Interestingly, though, this is an area where we have begun to see decentralized change with limited paid parental leave schemes being introduced at the state level in California, New Jersey, Washington, and Rhode Island and paid sick days being required at the municipal level in San Francisco and New York (Befort \& Budd, 2009). In addition, debates over employment issues in the United States have increasingly focused on enhancing general standards, such as the minimum wage, while prospects for labor law reform have faded after the defeat of the Employee Free Choice Act advocated by the union movement.

The other area where the United States continues to be an outlier is in its adherence to the employment-at-will rule barring any legal protection against wrongful dismissal or any entitlement to severance pay. There was some thought in the 1980 s that the American courts were gradually moving away from this doctrine as they began to craft a number of exceptions to it (Weiler, 1990). This proved a false dawn for just-cause protection for American workers, however, as the exceptions were narrowly interpreted and courts allowed 
organizations to reaffirm the at-will status of employees through declarations of this status in employee handbooks and other employment policies and documents (Befort \& Budd, 2009). The result is that when we talk about employment litigation in the United States, we continue to be mainly discussing employment discrimination litigation, which constitutes the majority of claims brought by employees through the courts.

So far I have considered the structure of rights in regard to the substantive protections and rights accorded to employees. Equally important in analyzing the structure of rights, though, is the question of which employees are covered by the laws in question. Employment statutes often limit the employees covered based on various criteria (Befort \& Budd, 2009). Sometimes exclusions are based on number of hours worked. For example, the Family and Medical Leave Act (FMLA), which provides limited unpaid leave for American workers, applies only if the employee has worked 1,250 or more hours for that employer over the past 12 months, excluding large number of part-time workers. Another common exclusion of coverage is of small employers. Title VII of the Civil Rights Act excludes employers with fewer than 15 employees. The FMLA includes an even broader small enterprise exclusion, only covering employers who have at least 50 employees within a 75 -mile radius.

Another important coverage issue is whether the worker meets the criteria or being considered an employee. Growing number of workers are either classified as independent contractors instead of employees or are classified as the employees of subcontractors or temp agencies rather than the organization where they do their primary work. If workers are not classified as employees of the organization, they are typically not protected by individual employment rights. Thus, the legal definition of employment becomes a major contested aspect of employment relations in the individual rights era. This was illustrated by the classic dispute in the lawsuit Microsoft v. Vizcaino, where a group of "perma-temps" who had worked for Microsoft at the company's own facilities for years sued to be covered by the provisions of the Employee Retirement Income Security Act (ERISA), which would entitle them to benefits similar to the regular Microsoft employees who worked alongside them (Van 
Jaarsveld, 2004). This dispute was ultimately settled on favorable terms for the workers, but battles over employment status continue to be a central feature of individual employment rights law.

The structure of rights in the individual employment rights system provides general sets of entitlements to workers. Yet it is also the case that the degree of protection varies widely. This is certainly the case in differences between national systems, but also importantly within countries. Within country inequality in the structure of rights is driven by differences in who is covered on both the employer and the employee side. As the next section will discuss, similar differences are also evident in the processes for enforcement of employment rights.

\section{System of Enforcement}

Individual employment rights on the books will mean little in the absence of a process to enforce them in case of violations. The way in which enforcement systems operate varies widely, with implications for how these rights are implemented in the workplace.

One major distinction is between inspection-based enforcement processes and adjudicatory-based enforcement processes. In inspection-based processes, some government agency is given the authority to inspect workplaces for compliance with employment standards and rights. These inspections can be routine, conducted according to some plan of inspection of workplaces, or complaint-driven, conducted in response to particular concerns about a particular workplace. Inspection-based processes tend to be used in the context of particular statutory schemes. For example, in the United States, which tends to have a more adjudicatorybased process for most statutes, the Occupational Safety and Health Act (OSHA) operates through an inspection-based system (Weil, 1996). Some countries, particularly in Southern Europe and Latin America, primarily have inspection based systems for the full range of individual employment rights (Piore \& Schrank, 2008). The key to these systems is that they bring the authority ofthe state to bear on the workplace through the office of the inspector 
engaged in the investigation. These systems can have advantages in their coverage of workplaces and their ability to integrate different employment rights into a more holistic evaluation of employment relations in the workplace. At the same time, they are vulnerable to underfunding of government agencies and lack of inspector expertise or resources to effectively monitor large number of workplaces (Amengual, 2014).

Adjudicatory processes, by contrast, are primarily driven by the filing of complaints against non-compliant employers and the adjudication of these complaints through a neutral adjudicatory forum. The key to the effectiveness of these processes is that they provide a fair process for determining whether individual employment rights violations have occurred and the imposition of sanctions by the adjudicating body in the event that there is liability. Complaints in an adjudicatory process can be brought by either public or private actors, depending on the specific process. Where these processes involve private parties bringing complaints, this can have the advantage of mobilizing private resources and broader sets of decentralized actors in enforcing employment rights. In the United States, for example, although employment discrimination complaints can be brought to court by either the public Equal Employment Opportunity Commission (EEOC) or by private parties, in practice the EEOC is able to bring only a few cases each year and around 96-98 percent of employment discrimination cases in the federal courts are brought by private parties (Equal Employment Opportunities Commission [EEOC], 2014). Although this leads to a much broader set of complaints being adjudicated, it also raises the problem that not all employees are equally able to bring complaints as private parties due to limited resources or lack of knowledge or experience with the law.

Among adjudicatory processes we also see variation in the types of bodies adjudicating cases. One major divide is between specialized tribunals and general courts. There is a long tradition of using specialized tribunals in the labor and employment area, reflecting the perceived need for specialized expertise in knowledge in this area as well as the advantages of tribunals designed to be accessible to the needs of employees. The British system of 
Employment Tribunals is a good example of this type of adjudicatory body. In the North American setting, these types of specialized tribunals have been used primarily for specific pieces of legislation, such as the Canadian system of Human Rights Tribunals that handle employment discrimination cases or the American system of workers compensation and unemployment insurance tribunals. In other areas of employment law, however, the general court system plays an important role. In Canada, employees can bring wrongful dismissal claims through the general court system, sometimes under expedited hearing procedures, and are typically able to recover substantially larger damages than provided for in statutory minimum severance pay (Colvin, 2006). In the United States, employment discrimination cases are heard through the general court system and typically tried before juries (Clermont \& Schwab, 2004). The United Kingdom also allows employees to opt to bring cases through the general courts rather than the employment tribunals, thereby avoiding the damage caps on the tribunals, albeit at the cost of the greater procedural complexity and expense of the courts, which thus tends to be an option utilized more often by relatively high-income employees.

Another variation is a distinctively American one, the substitution of private adjudication for the public courts. In North America there is a long-standing and well-developed system of labor arbitration for resolving disputes between unions and management regarding the enforcement of the terms of collective agreements. Over the last two decades there has been a parallel but very different development of the use of arbitration in the nonunion sector to resolve individual employment rights claims. This type of employment arbitration is something employers can require nonunion employees to agree to as a term and condition of employment, leading to it being commonly referred to as mandatory arbitration. Mandatory arbitration is a private process, not publicly regulated, and forecloses access by the employee to the courts. Although of recent origin, it is likely that mandatory arbitration now covers more workers in the United States than are represented by unions (Colvin, 2007). This is a very controversial development in the United States, which I will discuss further below. 
An additional distinction in enforcement systems is between rights-based and interest-based processes. Whereas the adjudicatory processes of litigation and arbitration focus on determination of employment rights, interest based systems such as mediation focus on producing consensual resolution of conflicts over these rights as well as the satisfaction of other interests of the parties. Mediation as an interest-based process is classically used to supplement and provide an alternative to the adjudicatory rights-based processes of litigation and arbitration. However, where effectively implemented, mediation can resolve a large proportion of conflicts and become a primary mechanism for dispute resolution (Ury, Brett, \& Goldberg, 1988). Conflict management systems theory suggests that enforcement systems will be most effective when they incorporate a combination of both rights based and interest-based processes that are accessible to employees for resolving conflict (Constantino \& Merchant, 1996; Lipsky et al., 2003).

\section{Mechanisms of Representation}

Establishment of an effective mechanism for representation of employees is important for ensuring the effectiveness of enforcement of individual rights and also for providing employee voice in the system. In the traditional collective bargaining-based industrial relations system, unions served this dual role of providing the ability to negotiate and enforce agreements protecting worker interests, as well as serving as a mechanism to give voice to workers' views and concerns. Put alternatively, representation by unions serves the interests of both equity and voice (Budd, 2004).

In addition to continuing to serve their direct representational role for workers who are covered by collective bargaining, unions are playing an additional role as a mechanism of representation for individual employment rights. Union-negotiated collective agreements themselves may provide strengthened protections against discrimination and other rights violations and union dispute resolution procedures like the American system of labor arbitration can provide an accessible and effective process for enforcing those rights. For 
workers not covered directly by collective bargaining, unions in various countries have made some efforts to represent employees in individual rights conflicts. In the United Kingdom, unions provide representation in some cases before the Employment Tribunals. In Germany, unions provide a form of legal representation insurance to their members, with representation of individual employees in cases before that country's public labor arbitration tribunals being provided by outside legal service firms retained by the unions for that purpose (Schneider, 2001). Meanwhile in Japan some new community-based unions provide representation in that country's new labor tribunal system to employees not covered by collective bargaining (Benson, 2012; Nakamura \& Nitta, 2013, chapter 14). Australian unions provide another interesting example of activity and expertise in this area with their more legally focused historical role under the old Award system (Colvin \& Darbishire, 2013).

Despite these various examples, the overall picture is not one in which unions provide the predominant mechanism of representation for individual employment rights in any of these countries. Why has the union role here been limited? One issue is financial. It is a cost for unions to provide this type of representation and so unions cannot afford to provide it on a widespread basis without some source of revenue. For that reason, we most often see unions providing these services to members who pay dues and not to the larger groups of nonunion employees. A system in which employees who are not covered by collective bargaining pay smaller than typical dues to unions in exchange for legal representation in the event of an individual rights dispute might have significant promise. However, there may be limitations to this model. For example, the community-based unions in Japan that have tried this approach have run into the problem that employees take out membership in the union only when they start running into an individual rights conflict at work and then proceed to drop membership once the conflict is resolved (Benson, 2012; Nakamura \& Nitta, 2013). A bigger problem to date has been a lack of sufficient interest by unions themselves in trying this model. This may be understandable given the various immediate pressure unions are under in many countries, but it is not promising for the longer term. 
Other types of collective actors like worker centers and Non-Governmental Organizations (NGOs) hold some potential as mechanisms of representation for individual employment rights. Worker centers have expanded in the United States in recent years and proven effective in addressing a number of employment law and immigration-related issues (Fine, 2006). Fine's leading study of worker centers in America shows many promising examples of how worker centers have been able to mobilize collective action in support of individual employee rights. Yet her comprehensive study of U.S. worker centers also reveals their limitations. Although there are over a hundred worker centers now established, the vast majority of them are focused on representing the interests of immigrant worker groups and emphasize dealing with issues around the nexus of employment and immigration issues. This is an important set of issues and the workers served represent a significant and disadvantaged minority group in the United States. However, the mechanism of workers centers with a few notable exceptions has not expanded to serve the larger population of American employees. Although it might be desirable to think about encouraging the establishment of a widespread system of worker centers that could represent all types of employees, we have not yet seen that type of system emerging.

A mechanism of representation that does have widespread reach is that provided by government agencies focused on employee rights. We do not typically think of the government or public agencies as providing representation, but I would argue that in practice they do serve this function in a number of respects. Certainly in investigating and prosecuting cases against employers that violate individual employment rights, government agencies represent the collective public interest in ensuring that employee rights are respected. But they also serve a more specific representational role in individual cases in pursuing justice on behalf of the individual employees involved. For example, in the United States the EEOC in pursuing individual employment discrimination cases both furthers the public interest in ensuring respect for the civil rights statutes and obtains specific damages and other remedies that are received by the individual employee claimants. This representational role of public agencies may be enhanced in investigator type systems such as those in Latin America where labor 
inspectors have a broad ambit to address a range of workplace concerns and different types of labor rights (Piore \& Schrank, 2008). In the Anglo-American countries, there is the potential for an expanded and more effective mechanism of representation to be provided by the recent advent of integrated public agencies in the employment area. The leading examples of this are the Australian Fair Work Commission and the Irish Workplace Relations Commission. Both of these examples are noteworthy for having a broad ambit of types of labor and employment rights that they cover and for being able to use a range of approaches to encourage respect for and implementation of these rights.

It is also important to recognize the limitations of government agencies as mechanisms of representation. One is the financial limitations that often plague public agencies. The reach of a public employment agency is often proscribed by the budget it is provided with. For example in the United States, the EEOC has only the resources to prosecute some 200-400 cases each year, whereas there are now over 100,000 complaints filed with the agency annually of which around 20,000 result in lawsuits being filed in the federal courts (EEOC, 2014). Countries and governments vary in their willingness to provide the resources to public employment agencies to fulfill their mission and extend their reach across the workforce, but the limits of their resources are a much more common theme than their breadth. A more fundamental limitation of public agencies as a mechanism of representation is their limited ability to provide authentic employee voice. Public agencies may stand in for the employee interest, but they do not directly represent employees in the same way that unions as the collective representative of employees do. In the individual employment rights realm, it is worth recognizing the traditional industrial relations insight that voice has an inherent value to employees (Budd, 2004). Processes for resolving individual rights conflict may be fair and provide equitable outcomes but still fall short if they do not provide employees with voice in ensuring their own rights are recognized and in shaping their own employment relationship (Budd \& Colvin, 2008). Some type of legal representation of individual employees is an important mechanism for providing the widespread representation that other mechanisms lack. Lawyers provide representation for employees with individual employment rights disputes 
in all types of countries and different legal settings. The expertise provided by legal representation enhances employees' ability to enforce individual employment rights and successfully win cases against employers. Representation by lawyers has so far received relatively little attention in industrial relations research, reflecting the field's focus on collective representation. However, lawyers are much more important actors in employment relations in the individual employment rights era, and research and theories need to address their role more directly.

Despite the effectiveness of expert legal representation, a major barrier to the widespread provision of legal services is the cost of financing it. Individual lawyers in most countries charge substantial fees, reflecting their professional training and the complexity of legal procedures and requisite knowledge to navigate them. As a result, retaining and paying for a personal legal representative is often the preserve of relatively high-income employees. Charity or pro bono legal services can supplement this for lower or middle income employees, but are not plausible as a widespread mechanism available for the majority of employees in need of representation. One alternative is the use of an insurance model to pay for representation given that most employees will only rarely need legal representation and might reasonably be willing to pay some small amount on an ongoing basis to ensure against this risk. The provision of legal services to members by German unions, discussed above, is a version of this. Collective labor efforts to fill this social insurance function for workers would be an example of one of the original forms of labor action identified by the Webbs over a century ago (Webb \& Webb, 1897), and its revival could provide an important role for unions in the individual rights era.

Another mechanism for financing legal representation that plays an important role in the United States is the use of contingency-fee arrangements. Under a standard contingencyfee arrangement, the employee seeking representation does not have to pay upfront or ongoing hourly fees to the lawyer. Instead the lawyer receives a percentage, typically 3040 percent, of the damages in the event the case is successful. In essence the cost of financing the 
case is shifted from the employee to the lawyer, who then also bears the financial risk of losing. Part of what makes this system effective is that the employment lawyer will typically be handling a number of cases at the same time. Even if only a portion of those cases are successful, the payoff over the full set of cases is sufficient to justify handling all the cases, including the ones where the employee loses and there are no damages to provide compensation for the lawyer. In this way, the middle or lower income employees who otherwise would be unable to afford legal representation are able to get a lawyer to handle their cases at no charge. The limitation, however, is that the lawyer's willingness to accept a case under a contingency-fee arrangement will be dependent on the prospects for success and the likely damages that will result. In the United States, the current situation is that most employment rights cases are handled by plaintiff lawyers on contingency-fee arrangements. However this system only functions to the degree that there are reasonable prospects of employees' winning cases and that there are relatively large damages available in cases.

\section{Sources of Power}

The three elements discussed so far, the structure of rights, the process of enforcement, and the mechanism of representation, provide the institutional framework of the individual employment rights system. However, it is also necessary to consider how this framework translates into changes in employer practices and how it affects the terms of the employment relationship. To analyze this issue, I draw on the traditional industrial relations concept of bargaining power, but translate it to address the nature of employee power in the individual employment rights system.

In collective negotiations, the bargaining leverage of unions derives from their theoretical or actual strike power (Katz, Kochan, \& Colvin, 2007). It is the threat of the economic costs imposed by a strike that creates the pressure and incentive for the employer to accede to union demands at the bargaining table. Thus union bargaining power is a function of the union's ability through a strike to impose costs on the employer by disrupting production, 
reducing sales, and ultimately affecting the employer's profits. Union bargaining power is also enhanced by the pressures on managers of having to deal with the consequences of a strike and especially the uncertainties inherent in a strike situation. The threat of union strike power then alters the decisions and behavior of management to the workers' advantage.

When we turn to employment relations in the individual employment rights era, the potential effects of legal claims can have a similar effect of providing a source of employee power that alters the decisions and behavior of managers to the advantage of employees. The characteristics of the individual employment rights system will influence the strength of this source of power and the degree to which it is likely to shift management behavior. I will explore this concept using the paradigmatic example of the U.S. litigation-based system for enforcing individual employment rights.

A key feature of the U.S.-based individual employment rights system is that although the structure of rights protected is relatively narrow, being largely restricted to employment discrimination, the litigation-based process of enforcement of these rights produces relatively large damage awards and substantial risks and costs for employers in attempting to defend claims. The damages awarded in American employment litigation are strikingly large compared to those in other countries. One study of employment discrimination cases in the federal courts decided in 1999 found a mean award of $\$ 336,291$ and a median of $\$ 150,500$, with employees winning 36.4 percent of cases that went to trial (Eisenberg \& Hill, 2003). Another study of wrongful dismissal cases in the California state courts found a median award of $\$ 296,991$, with employees winning 59 percent of trials (Oppenheimer, 2003). These relatively large damage awards represent the results of employees who were able to get a verdict at trial. Typically, American employment litigation is a long drawn-out process with extensive pre-trial discovery and preliminary motions that result in the dismissal of many cases before trial (Clermont \& Schwab, 2004). Although these preliminary proceedings provide a level of protection to employers against the most negative results to them of litigation, they also introduce a high level of procedural complexity into the system that substantially increases the 
costs for employers of defending cases. The uncertainty and costs of defending cases are exacerbated by the impact on individual managers who may have to devote substantial time to providing discovery of company files and documents, as well as being subject to extended interrogation by opposing plaintiff counsel in pre-trial discovery hearings where there are few limitations on the questions that a manager can be asked. Taken together it is unsurprising that while this litigation system is complex, unwieldy, and often difficult for employees to access, it nonetheless strikes fear in the hearts of American managers and motivates them to take strong actions to reduce the risk of litigation.

Much as bargaining power varies across groups of unionized workers, the strength of litigation power varies across different employees in the individual rights system. Litigation power will be a function of the employees' ability to bring claims forward and the outcomes if they do so. To the extent that individual employment rights laws provide protections for disadvantaged groups through prohibitions on discrimination or the provision of basic minimum standards, then there will be an inequality-reducing effect as these legal rights provide a source of power for otherwise disadvantaged groups. At the same time, if already advantaged, higher income employees are better able to access the legal system due to superior knowledge and resources for obtaining representation, then they will have greater litigation power, increasing their existing advantages and reinforcing existing inequalities.

We can see evidence of the influence of the American litigation system as a source of power in comparative research on how employers respond to legal threats and pressures. Simply looking at the extent of substantive legal protections, the United States appears as a particularly weak individual rights system with its continued adherence to the employment-atwill doctrine compared to just-cause protections in other countries. Nevertheless, the nature of the high riskhigh reward employment litigation system complicates the picture. In an interesting case study of dismissal practices in a multi-national company operating in Canada and the United States, Nielsen (1999) found a surprisingly similarity across the two countries. Although Canadian employment law requires substantial severance pay or notice for dismissal 
in the absence of just cause compared to the at-will rule in the United States, the company she studied actually spent similar amounts of time and resources in dealing with dismissals in both countries. While the company could have taken advantage of the at-will rule in the United States, in practice it was sufficiently concerned about the potential for employment litigation, including discrimination claims, that it devoted substantial managerial and legal resources to vetting dismissal decisions to avoid potential liability. In a larger scale quantitative survey, I compared the concerns over legal pressures and resulting impacts on hiring and firing decisions among establishments in Ontario in Canada and Pennsylvania in the United States (Colvin, 2006). An unexpected finding was that the managers of the establishments in the United States perceived greater pressures from the legal system than did their Canadian counterparts and these perceptions reflected a reality that their establishments were significantly more likely to have been subject to a legal claim or government agency investigation in the previous two years. What this suggests is that the litigation system-based source of power for employees in the United States may be mitigating the apparent employer advantage from the formal at-will rule.

\section{Patterns of Practices}

Individual employment rights will only have limited impact on employment relations unless they can alter the facts on the ground of the workplace by affecting the pattern of practices engaged in by employers. The public policy objective of declaring sexual harassment to be illegal, for example, is not simply to make a statement of principle, however worthwhile that is, but to get organizations to take concrete steps to prevent harassment of employees and to correct and remedy any instances of harassment that do occur. So to understand the nature of the individual employment rights regime, we need to analyze how it shapes the pattern of practices within the workplace.

In the paradigmatic example of the United States, as a result of employer concerns over the strengths of legal pressures, there has been widespread use of defensive human 
resource practices to attempt to reduce the risks of legal liability. Nonunion organizations began adopting internal grievance procedures in increasing numbers through the 1970 s and 1980s as employer concerns grew about this new litigation-based source of employee power (Edelman, 1990; Sutton, Dobbin, Meyer, \& Scott, 1994). This trend has continued and we now see American firms offering a wide range of dispute resolution procedures and advanced conflict management systems to respond to the concerns and complaints of their nonunion employees (Colvin, 2003a; Lipsky et al., 2003). Although not providing as elaborate a set of employment rights and due process protections as the strong grievance arbitration procedures used in American unionized workplaces, they nevertheless are mechanisms that allow significant number of workers to challenge unfair decisions in the workplace, and they represent an enhanced recognition of employee rights compared to the alternative of unchecked managerial authority (Colvin, 2003b).

The more general coverage of individual employment rights across the workforce allows this source of power to have a broader effect on employer practices than the more limited set of workers who benefit from collective representation by unions. The threat of union organizing does lead to better treatment of a segment of nonunion workers (Colvin, 2003a), but for the large segments of the economy where union organizing is no longer a significant threat to employers, the threat of litigation is the primary source of employee power likely to affect employer practices. In a study I conducted of the adoption of alternative dispute resolution procedures among nonunion employers, I found that strength of concerns about union organizing were a strong predictor of adopting more advanced ADR procedures, such as peer-review panels to review discipline and dismissal decisions (Colvin, 2003a). I was unable to find a similar relationship for a parallel set of questions about employer perceptions of the threat of litigation; however, for the simple reason that most employers had a uniformly high perception of the level of this threat and the importance of responding to it. In essence, virtually all employers were worried about litigation and taking steps to protect themselves against it. 
The impact of litigation pressures on employer practices is also evident in comparative employment relations research findings. As discussed in the previous section, my own research comparing organizations in the United States and Canada found that despite the existence of just-cause protection in Canada compared to the at-will rule in the United States, American employers perceived greater legal pressures than their Canadian counterparts. This American employer perception of a greater threat from the litigation sources of power results in a pattern of employment practices that alters the common perception of very lightly regulated American employment relations. I found that in practice the complexity of decisionmaking in the hiring and firing processes were similar between American and Canadian organizations (Colvin, 2006). American employers do not always behave like the unconstrained managers they are sometimes ascribed to be, and their concerns over litigation threats and pressures provide a compelling explanation for this behavior.

In recognizing the impact of individual employment rights as a source of power that alters employer patterns of practices, it is also important to acknowledge that not all employers will react the same way to these pressures and that these differences can also be a significant source of inequality in the experiences of workplace justice of different employees. Employers have a realm of freedom to make strategic choices about the set of practices or employment systems they want to adopt in managing their workforces (Kochan et al., 1986). This general observation about work and employment practices also holds true for the set of practices implicated in and affected by individual employment rights. For example, when we consider an area like employment discrimination law, these laws generally provide a set of rights against a certain category of adverse decisions by employers rather than a set of positive structures about what the employer practices and decisions have to be (Edelman, 1990). Similarly, employment standards laws are in most instances, particularly now in the Anglo-American countries, framed as minimum standards allowing substantial room for employer variation above these minima (Colvin \& Darbishire, 2013). 
Structuring individual employment rights to allow a good degree of employer discretion and choice has advantages in promoting flexibility of employment practices and encouraging experimentation in best practices. There is a danger, though, that placing too much of the authority on the employer to determine the nature of employment practices will produce excessive emphasis on the organization as the primary determinant of employment rights and result in inequality in justice across workplaces. This phenomenon, which I call organizational primacy (Colvin, 2013, chapter 11), has the potential to undermine the generality of individual employment rights. The danger of organizational primacy can be seen most acutely in the system of mandatory arbitration of employment rights that has become a major new practice in American employment relations.

\section{Applications of the Model}

How can this model help in analyzing issues relating to individual employment rights? I will illustrate its application by using it to analyze two different major phenomena in the resolution of individual employment rights disputes: the rise of mandatory arbitration of employment disputes and the use of integrated conflict management systems in organizations. Each of these examples will illustrate an additional feature of the model the existence of feedback loops between different components. In this sense the model shows the operation of the interconnected components as parts of a general individual employment rights system. However, I am using the term system here as a descriptive and analytical term, rather than in the normative sense that it was used historically in industrial relations theory by Dunlop (1958) or more recently in discussions of conflict management systems (Constantino \& Merchant, 1996; Lipsky et al., 2003).

The first application is the rise of mandatory arbitration. As I described earlier, under mandatory arbitration employers can require employees to agree to arbitrate any statutory or other legal claim against the employer through a private arbitration procedure designated in the contract drafted by the employer. Following a series of decisions of the U.S. 
Supreme Court, these mandatory arbitration procedures are enforceable and preclude access to the courts for resolving any claim covered by the arbitration agreement (Colvin, 2012). Although arbitration has a long and successful history of use in labor relations, the particular institutional structure of mandatory arbitration with its unilateral implementation at the choice of the employer has resulted in a process that tends to produce favorable results for employers. Whereas employees on average win some 37 percent of trials in federal courts and 57 percent of trials in state courts (Eisenberg \& Hill, 2003), employees win only 21 percent of hearings in mandatory arbitration (Colvin, 2011). Damage amounts are also substantially lower with a median award of only $\$ 36,500$ in mandatory arbitration compared to a median of $\$ 150,500$ in federal courts and $\$ 296,991$ in California state courts (Colvin, 2011). These lower prospects of success and reduced damages make it much harder for employment lawyers to justify accepting cases under mandatory arbitration because it limits the potential payoff under contingency-fee arrangements used to finance cases on behalf of lower and middle income employees who are unable to afford hourly fees for legal services. Recently the Supreme Court has further enhanced the value of mandatory arbitration to employers by holding that these arbitration agreements can require claims to be brought individually, effectively barring the use of class actions by employees covered by these procedures. 2 The result is that mandatory arbitration serves as a strong shield for employers against being subject to the risk and pressures of litigation.

Mandatory arbitration is a signal example of organizational primacy in individual employment rights since it allows the employer to determine the process of enforcement through which individual rights are pursued by employees. The resulting undermining of the mechanism of representation for lower income employees and diminution of the litigationbased sources of power result in reduced pressure on employers to alter their employment practices to respect individual employment rights. This is obviously a very specific American phenomenon that is a product of U.S. Supreme Court decisions that are reframing the uniquely American system of individual employment rights litigation. However, it also has broader lessons for employment relations theory and policy. From a research and theory standpoint, 
what it shows is the importance of the interconnections amongst the different elements of the individual employment rights-based system in the model that I have outlined. From a policy standpoint it shows the importance of understanding and addressing the specific features of the individual employment rights system, because these features can have profound effects on the nature of employment relations in the individual rights era.

The second phenomenon to consider in applying the model is the adoption of conflict management systems by organizations. Early innovations in the area of alternative dispute resolution looked at the impact of specific practices and procedures, such as the adoption of arbitration, mediation, or ombudspersons. By contrast the conflict management systems approach suggests that more effective resolution of conflict will occur where there are a combination of different procedures and practices used in conjunction with one another (Constantino \& Merchant, 1996). Lipsky et al. (2003) argue that effective systems, which they term integrated conflict management systems, will include five characteristics: a broad scope, covering all employees and types of problems; a culture that welcomes dissent and encourages resolution of conflict through negotiation; multiple access points to the system; multiple options for resolution, including both rights based and interest-based options; and support structures for the system. In another version of the conflict management systems argument, Bendersky (2003) suggests that effective systems should include three elements: rights based processes; negotiated processes; and interest-based neutrals.

The idea of conflict management systems has been a popular normative concept for thinking about organizational approaches to conflict resolution design. However, there has been only a small amount of empirical work systematically examining its impact, notably Bendersky's (2007) study of a Canadian government agency and Roche and Teague's (2012b) study of conflict management systems in Irish firms (see generally Roche \& Teague, 2014, chapter 12). Despite the limited empirical evidence to date, the strong consensus in the dispute resolution field is that conflict management systems provide a best practice model for organizations to follow. Yet a common theme among case studies of conflict management 
systems is their fragility and lack of sustainability. In their leading work in this area, Lipsky et al. (2003) noted the importance of having an organizational ADR champion to encourage the adoption and operation of integrated conflict management systems. In the absence of or following the departure of this ADR champion, these systems tended to fall into disuse and abandonment. But why should conflict management systems be so dependent on an individual champion if they are indeed effective systems for dealing with employment rights disputes?

Applying the model developed in this chapter, the key problem with conflict management systems developed at the organizational level is that they represent innovation in only part of a broader system. An organizational conflict management system can emerge as an innovation in organizational employment practices in response to pressures from employment conflicts. This organizational innovation then provides a new enforcement system for employees with employment rights disputes, but these types of organizational systems are often lacking in effective mechanisms of representation. Many are introduced in nonunion settings lacking collective representation from unions. Because they are internal systems, participation in them by outsider lawyers is generally unwelcome. The result is that the institutional framework of organizational conflict management systems is not one well suited to the production of sources of power for employees. It may be that these systems are sustainable for some period of time based on internal support for the principle of effective conflict management led by an ADR champion. However, the employee sources of power are necessary over time for most organizations to pressure employers to adopt practices that are responsive to individual employee rights.

\section{CONCLUSIONS}

There are two general themes that can be drawn from the discussion presented there. The first relates to the role of organizations in individual rights employment relations. Individual employment rights are typically enacted as laws providing rights to employees across the whole economy not particular to any individual employer - in contrast for example to an 
organizational or enterprise level collective agreement. Some researchers have also questioned the importance of the individual employer in an era where long-term standard employment relationships have broken down and organizational forms have become increasingly complex and intertwined into network structures and production chains that often span the globe. I am suggesting that the institutional structure of the individual employment rights system has actually empowered organizations as the central actors in the system and the key parties who determine the nature of employment relations that workers experience. This is a consequence of both the variation in pressure exerted on different employers from individual employment rights conflict and the variation in employer responses in terms of adopting different patterns of employment practices.

The second general theme concerns the growth of inequality in justice in employment. There has rightly been much attention to the growth of income inequality and the problems it poses for societies and economies. My argument is that along with this trend, there is a growing inequality in access to justice in the workplace. Rather than individual employment rights providing a universal structure of rights and fair treatment, accessible to all workers, there is great variation in practice in the protections and fairness accorded to workers. This inequality is not inherent or accidental, but rather a product of the institutional structure of the individual employment rights system as currently constituted.

I began with a call for industrial relations research and theory to more fully address the issues and implications posed by the rise of the individual employment rights era in employment relations. The model I have proposed seeks to provide an approach to understanding how individual employment rights affect employment relations. It focuses the analysis on the elements that connect the structure of rights that are enacted to the patterns of employment practices in the workplace. My argument is that the systems for enforcement of these rights and the mechanisms of representation for the employees affected are as important as the substantive rights themselves in determining the impact of the individual rights regime. These three elements combine to determine the degree to which the individual employment 
rights serve as an effective source of power for employees in relation to their employers. The establishment of these sources of power is what then results in the individual rights regime producing an effect on the employers' patterns of practices in the workplace and ultimately determining the nature and character of the employment relationship.

For industrial relations to remain relevant and thrive as a field it is important that it takes on the new issues of work and employment such as those posed by the rise of individual employment rights. This does not mean abandoning the basic insights of our field, because, as I have argued here, our foundational concepts and focus on analyzing institutions, conflict, and power remain relevant and yield insights in understanding the nature of employment relations in the individual rights era. Rather, our task going forward is to take these tools and ideas and use them to address the problems of the new world of work that confronts us.

\section{NOTES}

1. The key decision enabling mandatory arbitration to be used for disputes involving statutory employment rights was Gilmer v. Interstate/Johnson Lane (1991). For a more detailed recent discussion of the law in this area see: Stone and Colvin (2015).

2. AT\&T v. Concepcion (2011). 


\section{REFERENCES}

Amengual, M. (2014). Pathways to enforcement: Labor inspectors leveraging linkages with society in Argentina. Industrial and Labor Relations Review, 67(1), 3-33.

AT\&T v. Concepcion, 563 U.S. 333 (2011).

Befort, S. F., \& Budd, J. W. (2009). Invisible hands, invisible objectives: Bringing workplace law \& public policy into focus. Stanford, CA: Stanford University Press.

Bendersky, C. (2003). Organizational dispute resolution systems: A complementarities model. Academy of Management Review, 28(4), 643-656.

Bendersky, C. (2007). Complementarities in organizational dispute resolution systems: How system characteristics affect individuals' conflict experiences. Industrial and Labor Relations Review, 60(2), 204-224.

Benson, J. (2012). Alternative dispute resolution in Japan: The rise of individualism. International Journal of Human Resource Management, 23(3), 511-527.

Budd, J. W. (2004). Employment with a human face: Balancing efficiency, equity, and voice. Ithaca, NY: ILR Press.

Budd, J. W., \& Colvin, A. J. S. (2008). Improved metrics for workplace dispute resolution procedures: Efficiency, equity, and voice. Industrial Relations, 47(3), 460-479.

Clegg, H. A. (1970). The system of industrial relations in Great Britain. Oxford: Blackwell.

Clermont, K. M., \& Schwab, S. J. (2004). How employment discrimination plaintiffs fare in federal court. Journal of Empirical Legal Studies, 1(2), 429-458.

Colvin, A. J. S. (2003a). Institutional pressures, human resource strategies and the rise of nonunion dispute resolution procedures. Industrial and Labor Relations Review, 56(3), 375-392.

Colvin, A. J. S. (2003b). The dual transformation of workplace dispute resolution. Industrial Relations, 52(4), 712-735.

Colvin, A. J. S. (2006). Flexibility and fairness in liberal market economies: The comparative impact of the legal environment and high performance work systems. British Journal of Industrial Relations, 44(1), 73-97. 
Colvin, A. J. S. (2007). Empirical research on employment arbitration: Clarity amidst the sound and fury? Employee Rights and Employment Policy Journal, 11(2), 405-447.

Colvin, A. J. S. (2011). An empirical study of employment arbitration: Case outcomes and processes. Journal of Empirical Legal Studies, 8(1), 1-23.

Colvin, A. J. S. (2012). American workplace dispute resolution in the individual rights era. International Journal of Human Resource Management, 23(3-4), 459-475.

Colvin, A. J. S. (2013). Organizational primacy after the demise of the organizational career: Employment conflict in a post-standard contract world. In H. Arthurs \& K. Stone (Eds.), Employment regulation after the demise of the standard employment contract: Innovations in regulatory design (pp. 194-210). New York, NY: Russell Sage.

Colvin, A. J. S., \& Darbishire, O. (2013). Convergence in industrial relations institutions: The emerging Anglo-American model? Industrial and Labor Relations Review, 66(5), 1045-1075.

Colvin, A. J. S., \& Gough, M. D. (2015). Individual employment rights arbitration in the United States: Actors and outcomes. Industrial and Labor Relations Review, 68(5), 1019-1042.

Commons, J. R. (1909). American shoemakers, 1648-1895. Quarterly Journal of Economics, 24(4), 39-83.

Constantino, C. A., \& Merchant, C. S. (1996). Designing conflict management systems. San Francisco, CA: Jossey-Bass.

Currie, D., \& Teague, P. (2016). Economic citizenship and workplace conflict in AngloAmerican industrial relations systems. British Journal of Industrial Relations, 54(2): 358-384.

Dix, G., Sisson, K., \& Forth, J. (2009). Conflict at work: The changing pattern of disputes. In W. Brown, A. Bryson, J. Forth, \& K. Whitfield (Eds.), The evolution of the modern workplace (pp. 176-200). Cambridge: Cambridge University Press.

Doellgast, V., \& Greer, I. (2007). Vertical disintegration and the disorganization of German industrial relations. British Journal of Industrial Relations, 45(1), 55-76. 
Dunlop, J. T. (1958). Industrial relations systems. New York, NY: Holt.

Edelman, L. B. (1990). Legal environments and organizational governance: The expansion of due process in the American workplace. American Journal of Sociology, 95, 1401-1440.

Eisenberg, T., \& Hill, E. (2003). Arbitration and litigation of employment claims: An empirical comparison. Dispute Resolution Journal, 58(4), 44-55.

Equal Employment Opportunities Commission (EEOC). (2014). Enforcement and litigation statistics. Retrieved from http://www.eeoc.gov/eeoc/statistics/enforcement/index.cfm. Accessed on January 10, 2014.

Estlund, C. (2010). Regoverning the workplace. New Haven, CT: Yale University Press. Fine, J. (2006). Worker centers: Organizing communities at the edge of the dream. Ithaca, NY: Cornell University Press.

Flanders, A. (1970). Management and unions: The theory and reform of industrial relations. London: Faber.

Fox, A., \& Flanders, A. (1969). The reform of collective bargaining: From Donovan to Durkheim. British Journal of Industrial Relations, 7(2), 151-180.

Gilmer v. Interstate/Johnson Lane, 500 U.S. 20 (1991).

Godard, J. (2014). Labor-management conflict. In W. K. Roche, P. Teague, \& A. J. S. Colvin (Eds.), The Oxford handbook of conflict management in organizations. Oxford: Oxford University Press.

Hyman, R. (1972). Strikes. London: Fontana.

Hyman, R. (1975). Industrial relations: A Marxist introduction. London: Macmillan.

Katz, H. C., Kochan, T. A., \& Colvin, A. J. S. (2007). An introduction to collective bargaining and industrial relations (4th ed.). New York, NY: McGraw Hill Irwin.

Kaufman, B. (1993). The origins and evolution of the field of industrial relations. Ithaca, NY: ILR Press.

Kelly, J. (1998). Rethinking industrial relations: Mobilization, collectivism, and long waves. London: Routledge. 
Kerr, C., Dunlop, J., Harbison, F., \& Myers, C. (1964). Industrialism and industrial man. Cambridge, MA: Harvard University Press.

Kochan, T. A., Katz, H. C., \& McKersie, R. B. (1986). The transformation of American industrial relations. New York, NY: Basic Books.

Lipsky, D. B., Seeber, R. L., \& Fincher, R. D. (2003). Emerging systems for managing workplace conflict: Lessons from American corporations for managers and dispute resolution professionals. San Francisco, CA: Jossey-Bass.

Nakamura, K., \& Nitta, M. (2013). Organizing nonstandard workers in Japan: Old players and new players. In K. V. W. Stone \& H. Arthurs (Eds.), Rethinking workplace regulation: Beyond the standard contract of employment (pp. 253-270). New York, NY: Russell Sage.

Nielsen, L. B. (1999). Paying workers or paying lawyers: Employee termination practices in the United States and Canada. Law \& Policy, 21(3), 247-282.

Oppenheimer, D. B. (2003). Verdicts matter: An empirical study of California employment discrimination and wrongful discharge jury verdicts reveals low success rates for women and minorities. U.C. Davis Law Review, 37, 511-566.

Piore, M., \& Safford, S. (2006). Changing regimes of workplace governance, shifting axes of social mobilization, and the challenge to industrial relations theory. Industrial Relations, 45(3), 299-325.

Piore, M., \& Schrank, A. (2008). Toward managed flexibility: The revival of labor inspection in the Latin world. International Labour Review, 147, 1-23.

Roche, W. K., \& Teague, P. (2012a). The growing importance of workplace ADR. International Journal of Human Resource Management, 23(3), 447-458.

Roche, W. K., \& Teague, P. (2012b). Do conflict management systems matter? Human Resource Management, 51(2), 231-258.

Roche, W. K., \& Teague, P. (2014). Conflict management systems. In W. K. Roche, P. Teague, \& A. J. S. Colvin (Eds.), The Oxford handbook of conflict management in organizations (pp. 250-272). Oxford: Oxford University Press.

Roche, W. K., Teague, P., \& Colvin, A. J. S. (Eds.). (2014). The Oxford handbook of conflict 
management in organizations. Oxford: Oxford University Press.

Schneider, M. (2001). Employment litigation on the rise? Comparing British employment tribunals and German labor courts. Comparative Labor Law \& Policy Journal, 22, 261-280.

Stone, K. V. W., \& Colvin, A. J. S. (2015). The arbitration epidemic: The use of mandatory arbitration to deprive consumers and workers of their rights. Washington, DC: Economic Policy Institute (EPI). EPI Briefing Paper \#414.

Sutton, J. R., Dobbin, F., Meyer, J., \& Scott, W. R. (1994). The legalization of the workplace. American Journal of Sociology, 99, 944-971.

Ury, W. L., Brett, J. M., \& Goldberg, S. B. (1988). Getting disputes resolved: Designing systems to cut the costs of conflict. San Francisco, CA: Jossey-Bass.

Van Jaarsveld, D. D. (2004). Collective representation among high-tech workers at Microsoft and beyond: Lessons from WashTech/CWA. Industrial Relations, 43(2), 364-385.

Webb, S., \& Webb, B. (1897). Industrial democracy. London: Longmans, Green and Co.

Weil, D. (1996). If OSHA is so bad, why is compliance so good? Rand Journal of Economics, 27(3), 618-640.

Weiler, P. C. (1990). Governing the workplace: The future of labor and employment law. Cambridge, MA: Harvard University Press.

Wheeler, H. N., Klaas, B. S., \& Mahony, D. M. (2004). Workplace justice without unions. Kalamazoo, MI: W.E. Upjohn Institute. 